\title{
An ocean of surprises - Trends in human use, unexpected dynamics and governance challenges in areas beyond national jurisdiction
}

\author{
Andrew Merrie ${ }^{\mathrm{a}, *}$, Daniel C. Dunn ${ }^{\mathrm{b}}$, Marc Metian ${ }^{\mathrm{a}}$, Andre M. Boustany ${ }^{\mathrm{b}}$, Yoshinobu Takei ${ }^{\mathrm{c}}$, \\ Alex Oude Elferink ${ }^{\mathrm{d}, \mathrm{e}}$, Yoshitaka Ota ${ }^{\mathrm{f}}$, Villy Christensen ${ }^{\mathrm{f}}$, Patrick N. Halpin ${ }^{\mathrm{b}}$, \\ Henrik Österblom ${ }^{\text {a }}$ \\ a Stockholm Resilience Centre, Stockholm University, Stockholm, Sweden \\ ${ }^{\mathrm{b}}$ Marine Geospatial Ecology Lab, Nicholas School of the Environment, Duke University, Durham, NC, USA \\ ${ }^{\mathrm{c}}$ Walther Schücking Institute for International Law, University of Kiel, Kiel, Germany \\ ${ }^{\mathrm{d}}$ Netherlands Institute for the Law of the Sea, Utrecht University, Utrecht, Netherlands \\ e K.J Jebsen Centre for the Law of the Sea, University of Tromsø, Tromsø, Norway \\ ${ }^{\mathrm{f}}$ Nereus Program, Fisheries Centre, University of British Columbia, BC, Canada
}

\section{A R T I C L E I N F O}

\section{Article history:}

Received 19 October 2013

Received in revised form 16 April 2014

Accepted 24 April 2014

Available online 29 May 2014

\section{Keywords:}

High seas

Areas beyond national jurisdiction

Fisheries

Ocean governance

Marine ecosystems

Surprise

\begin{abstract}
A B S T R A C T
The expanse of ocean which makes up all marine areas beyond national jurisdiction has been characterized as the last frontier of exploitation on the planet, a figurative final "Wild West". Existing users of areas beyond national jurisdiction, with the exception of fisheries, currently have a limited footprint there as a consequence, in part, of substantial hurdles in technological development that need to be overcome before many resources can be extracted at a commercially viable scale. However, we argue surprise shifts perpetuated by both established and emerging users could lead to an expansion in actors taking opportunities to chase lucrative resources that they are currently constrained from exploiting. Rapid development could also lead to a "crowded ocean" due to the multiplication of users which could present a problem given the current lack of a unified institutional framework for governance connecting the different user groups. Here, we have collated trends in human use of areas beyond national jurisdiction and offer a framework for, and examples of, unexpected dynamics relevant to living and non-living marine resources. Such an approach is necessary in order to begin to mobilize an adequate governance response to changing conditions and uses of areas beyond national jurisdiction. This governance response must be able to govern established or potential users, be flexible and adaptive in response to unexpected and unpredictable dynamics and be able to transform in the face of unpredictable future uses of this vast area. Here we present a set of institutional design principles as a first tentative step in this direction.
\end{abstract}

(c) 2014 Elsevier Ltd. All rights reserved.

\section{Introduction}

Human ingenuity and demand for raw materials is continuously leading to innovations that have increased our ability to access natural resources. Technological innovation and changing markets can consequently modify how humans interact with their environment, potentially with negative effects for both ecosystems and human well-being (Olsson and Galaz, 2012). While the effects of such dynamics are evident in terrestrial and coastal ecosystems (Rockström et al., 2009), it was long thought that the open-ocean

\footnotetext{
* Corresponding author at: Stockholm Resilience Centre, Stockholm University, SE-106 91 Stockholm, Sweden. Tel.: +0046 (0)73 4612366.

E-mail address: andrew.merrie@stockholmresilience.su.se (A. Merrie).
}

and deep-seas were too distant and vast to be affected in a similar manner (as formulated in "The Freedom of the Seas"; Grotius, 1609). However, evidence of the expansion of long line fisheries (Myers and Worm, 2006), effects of deep-sea fishing (Clark, 2001), and ocean acidification as a result of anthropogenic climate change (Orr et al., 2005), among many other factors, has led to concerns that such areas may be highly impacted by human activities (Halpern et al., 2008). This has, in turn, led to calls for conservation and the use of the precautionary approach to address the threats facing these areas beyond national jurisdiction (Barbier et al., 2014; Norse et al., 2012; Van Dover et al., 2011).

Since the 1950s, the international community has made steady progress in developing legal and governance instruments to address the increasing number of stressors on areas beyond national jurisdiction (Fig. 1). Most notably, the Law of the Sea 


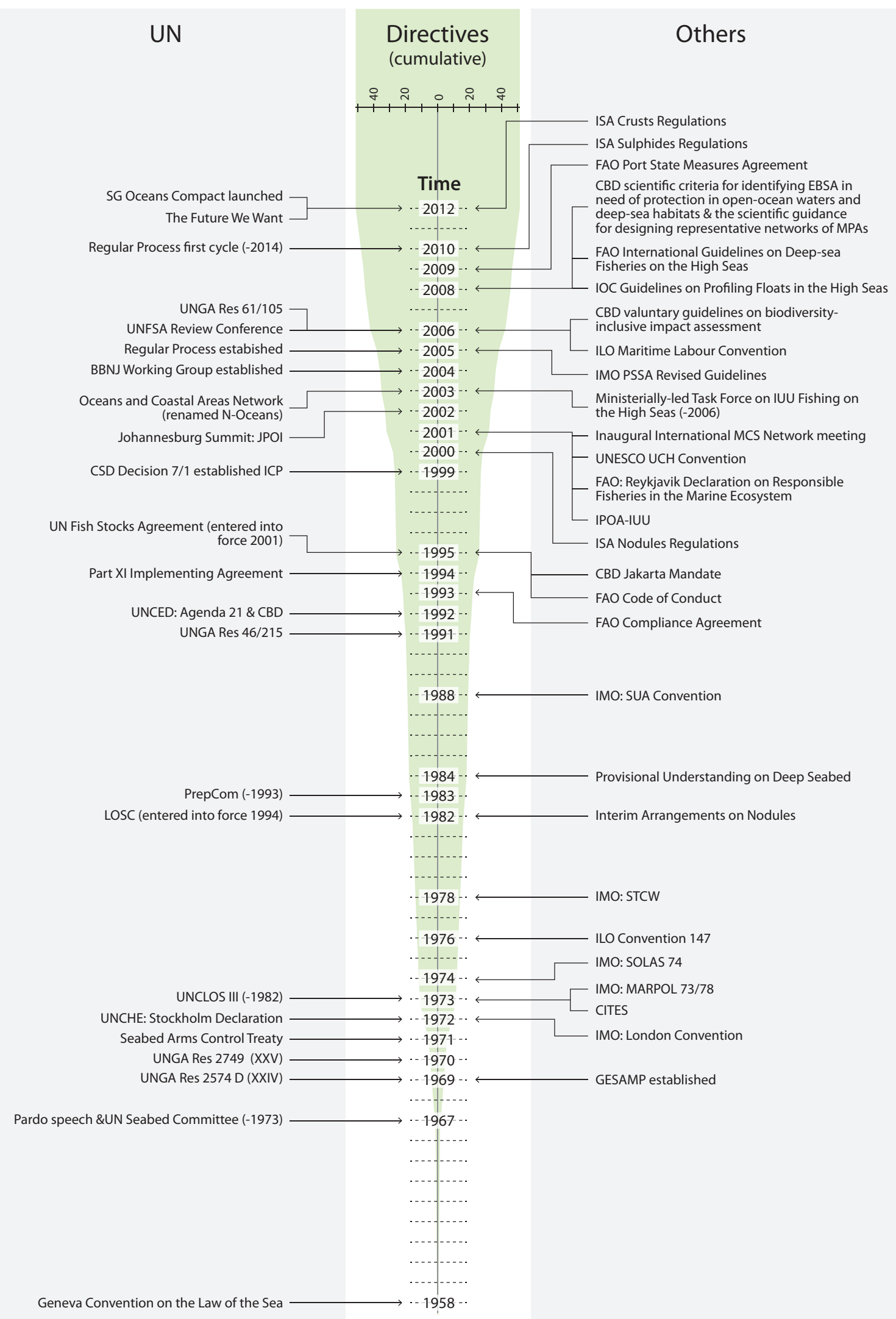

Fig. 1. Timeline of significant legal and governance developments relevant to the "High Seas", the "Area" and "Areas Beyond National Jurisdiction" from 1950 to 2012.

Convention (UN LOSC, 1982) and its Implementing Agreements have established a general legal framework for activities in areas beyond national jurisdiction, which has been implemented at global and regional levels by sectoral regimes (Oude Elferink,
2012). Activities in areas beyond national jurisdiction are now subject to a complex and growing network of regulations.

To better contextualize governance challenges associated with future human use of areas beyond national jurisdiction, we here 
review quantitative temporal trends in human use of this region. Previous studies rarely provide empirical evidence of trends in use. Typically, such studies cite static "snapshot" models of human uses (i.e., Halpern et al., 2008; e.g., Dunn et al., 2011; Ban et al., 2014), or describe uses and offer examples or expert opinion (RamirezLlodra et al., 2011). Other studies simply take increasing use of areas beyond national jurisdiction as a given (Rice et al., 2011) or focus on a single user group without considering how they interact with other users (vis. Fisheries; Sea Around Us Project, 2013.

Beyond trends in human use, the potential for unexpected dynamics are considered, where for example, commercial exploitation could occur at a more rapid pace than governance institutions will likely be able to respond (e.g., Berkes et al., 2006). Here, we consider unexpected dynamics denoted as 'surprise' (Galaz et al., 2011) following La Porte (2007b), a leading thinker in the crisis management literature. La Porte makes a clear delineation between 'emergencies' which are fairly well-understood unfolding situations that, although somewhat predictable, evolve and become more challenging to deal with over time. In this paper we categorize these situations as 'slow burning emergencies.' By contrast, La Porte (2007b) defines a qualitatively different kind of unexpected dynamic denoted as 'rude surprises.' Here, following the La Porte terminology we offer examples of potential 'slow burning emergencies' and 'rude surprises' that may arise in the governance of areas beyond national jurisdiction. In light of ongoing discussions regarding the development of mechanisms to allow conservation of areas beyond national jurisdiction, we consider design principles for organizations and institutions that enable them to be highly effective and reliable when facing the unexpected. The overarching aim of this paper is to link human use trends and surprise dynamics while considering the governance challenge facing the largest commons resource on the planet: ocean areas beyond national jurisdiction.

\section{Current and emerging users of areas beyond national jurisdiction}

\subsection{Capture fisheries}

High seas fishing activities have a long history, but a considerable increase occurred following World War II, when major technical development occurred globally in capture fisheries (Bavinck, 2011). This technological development (including improved freezing and processing capacity on board vessels, nylon nets and deep water trawls) allowed fishermen to catch larger quantities, further from shore. The expansion in landings was consistent from 1950 to the early 1990s, before leveling off in recent decades (Fig. 2). Despite the minor quantities landed from the high seas when compared to total global marine production (less than 15\% in 2006, Sea Around Us Project, 2013), there are indications that the offshore marine resources are substantially exploited (Sibert et al., 2006). The global landings and effort trend lines in areas beyond national jurisdiction (Fig. 2) illustrate that, while landings and value of catches have stagnated, fishing effort continues to grow at strong rates. Thus competition among countries operating distant water fleets is increasing as larger fleets attempt to catch increasingly limited resources. Further, since 1975 the lack of growth in the commercial value of species

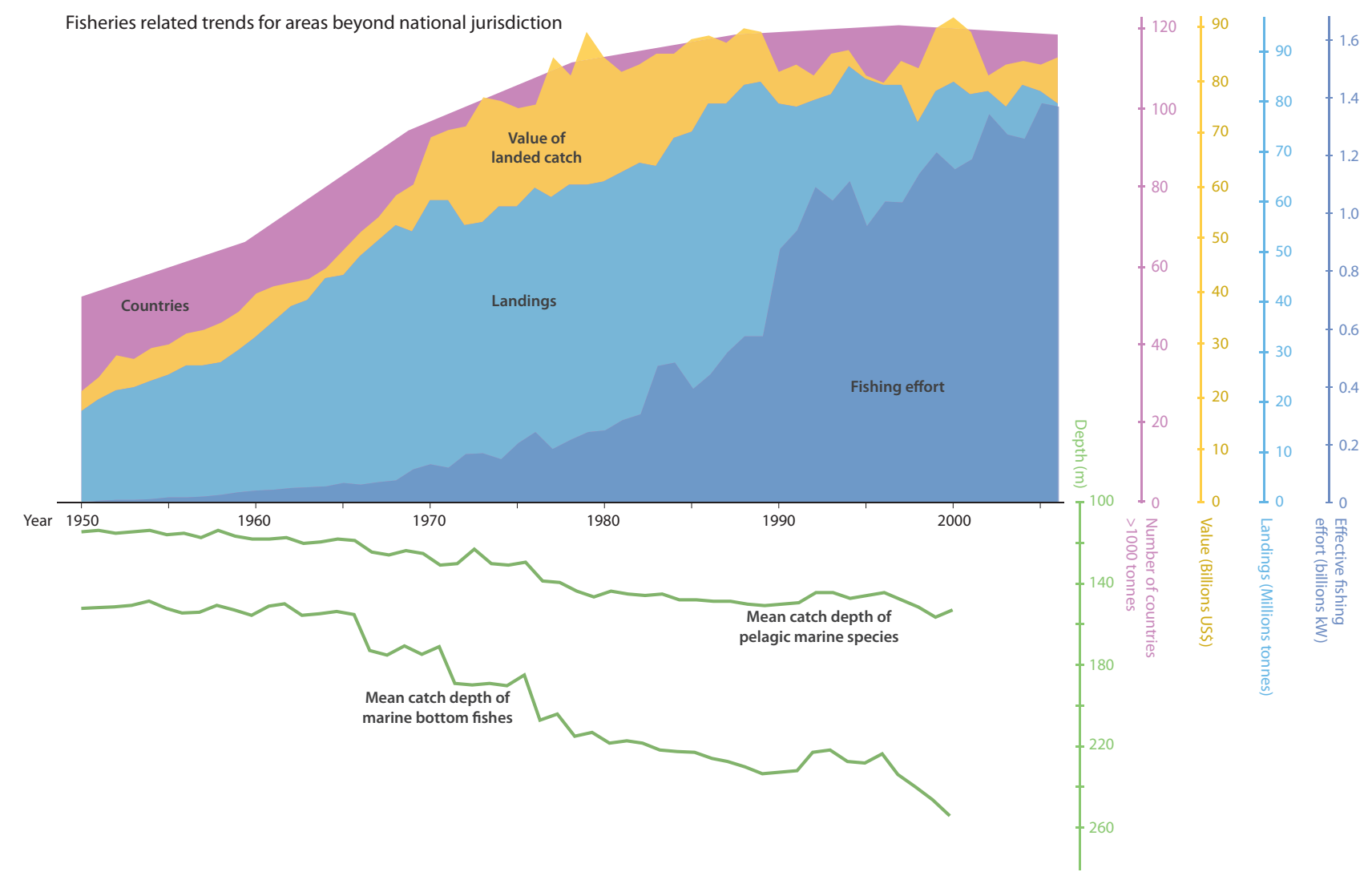

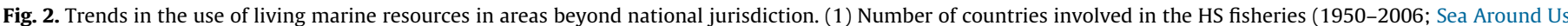

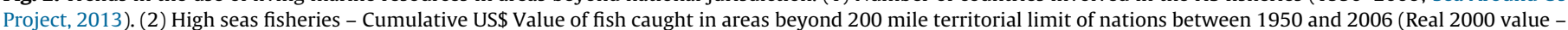

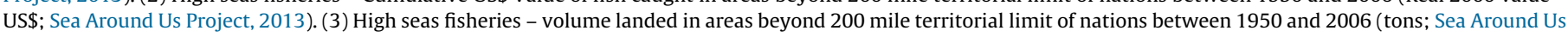

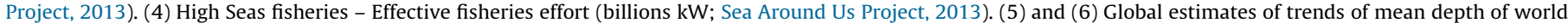
capture fisheries catches from 1950 to 2001 for all marine fishes including pelagic species and for benthic species only Adapted from Morato et al. (2006). 
Table 1

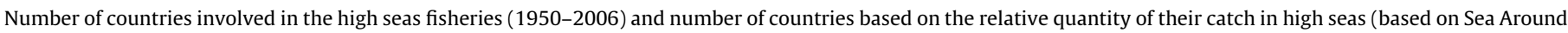
Us dataset Sea Around Us Project, 2013).

\begin{tabular}{|c|c|c|c|c|c|c|c|}
\hline & 1950 & 1960 & 1970 & 1980 & 1990 & 2000 & 2006 \\
\hline Number of countries participating to High Sea (HS) Fisheries & 52 & 66 & 94 & 112 & 119 & 121 & 119 \\
\hline Catch over $0.1 \%$ of the total HS catch & 35 & 35 & 44 & 51 & 52 & 56 & 57 \\
\hline Catch over $1 \%$ of the total HS catch & 14 & 12 & 21 & 23 & 20 & 20 & 21 \\
\hline Catch over $5 \%$ of the total HS catch & 5 & 5 & 5 & 7 & 6 & 7 & 8 \\
\hline Catch over $10 \%$ of the total HS catch & 2 & 3 & 1 & 2 & 3 & 2 & 1 \\
\hline Catch over $15 \%$ of the total HS catch & 1 & 2 & 1 & 1 & 0 & 0 & 0 \\
\hline Catch over $20 \%$ of the total HS catch & 1 & 2 & 1 & 0 & 0 & 0 & 0 \\
\hline
\end{tabular}

landed from the high seas (Sea Around Us Project, 2013), combined with an increase in landings implies a decrease in average value per unit landed (Fig. 2). This is even the case for species that are still relatively profitable, such as Pacific Bluefin tuna (Thunnus orientalis) and toothfish (Dissostichus spp.; Sea Around Us Project, 2013). Increasing utilization of high seas fish species has become possible through expansion of the areas (Myers and Worm, 2006) and depths (Pauly et al., 2002; Morato et al., 2006) in which fishing fleets operate, but has resulted in decreasing catch per unit effort and increased costs. Increased fuel and labor costs have also reduced profit margins of industrial fishers and increased the cost and economic risk of high seas fishing.

Despite the stagnation of landings and the documented reduction in catch per unit effort, it is unlikely that there will be a reduction in high seas fishing activities, as the "sunk costs" (in capital investment such as ships and gear) is redirected to the exploitation of new species ("taxonomic expansion"). This expansion often comes with limited biological and ecological understanding of the implications of such fisheries (Blight et al., 2010; Norse et al., 2012), which possibly include a substantial expansion of krill Euphausia superba catches (Nicol et al., 2012). The significant increase in the depth of fishing is also an important factor (Morato et al., 2006; Villasante et al., 2012). Deep-sea fisheries are regularly conducted at depths below $1200 \mathrm{~m}$ in every ocean basin (Morato et al., 2006). Fishing at such depths means that shallow seamounts are open to exploitation by deep-sea fisheries. Seamounts have been shown to be areas of relatively high species richness (de Forges et al., 2000; O'Hara, 2007; Morato et al., 2010a) and productivity (Boehlert and Genin, 1987; Boehlert, 1988; Pitcher and Bulman, 2007) and are thus important for the functioning of deep-sea ecosystems. For this reason numerous seamount chains have been described as meeting the criteria for Ecologically or Biologically Significant Areas through the Convention on Biological Diversity regional expert workshop process (CBD, 2012a; Dunn et al., in press). Habitats that support such a designation are vulnerable to deep-sea trawling and deep-sea mining (Rogers, 1994; Koslow et al., 2000; Clark, 2001; Clark and Rowden, 2009; Morato et al., 2010b).

There has been a notable increase in the number of countries involved in high seas fishing since 1950, a trend that mimics the developments in landings and value. This increase has reached a level where the vast majority of coastal countries now have at least a minimal stake in areas beyond national jurisdiction through fisheries. According to the Sea Around Us Project (2013) high seas fisheries in 1950 were principally dominated by American and Japanese distant water fishing fleets (32.8\% and $14.8 \%$ of the total high sea catch, respectively). Only 20 countries reported landings over 1000 metric tons in 1950, whereas 95 countries reported such amounts in 2006 (Sea Around Us Project, 2013). The total number of countries fishing on the high seas rose from 52 countries in 1950 to 119 in 2006 (Sea Around Us Project, 2013). This dramatic increase in the number of active countries has implications for political alliances and the formation of new regional fisheries management organizations and arrangements. Chile, China, Thailand, South Korea, Japan, Taiwan, Indonesia and Malaysia currently dominate fishing in the high seas, accounting for $54.2 \%$ of the total high seas landings in 2006 (shares comprises between 5.1 and 10.4\%; Sea Around Us Project, 2013 (Table 1).

\subsection{Aquaculture}

Aquaculture has expanded dramatically as a consequence of increasing demand and reduced supply from wild fish stocks (Beveridge et al., 2013). Although there are technological and financial challenges to developing aquaculture beyond the exclusive jurisdiction of a single state (details of major costs reviewed in Klinger and Naylor, 2012), this practice is likely to expand. High value species are likely to be the "prototype" species for such expansion, while lower value, low maintenance species (especially non-fed species) may be used if such operations could be coupled with other high seas activities (e.g., fish farming connected to an offshore oil or mining platform), that could reduce logistic costs. A further constraint is that the majority of offshore areas are not as rich in nutrients as coastal areas, which places limits on the species that can be farmed. Yet, if appropriate incentives and technologies are developed, high seas aquaculture may become a viable option to address food security by meeting increasing demand for fish and seafood products (Tacon and Metian, 2013). One of the most promising options currently being tested are mobile cage operations such as the "ocean drifter" manned or autonomous cages capable of low-speed, self-propulsion operating in oceanic gyres (Goudey, 2009).

\subsection{Oil and gas exploration and production}

In addition to the increasing depth of fishing activities, technological advances are also substantially increasing the average depth of non-renewable resource extraction (e.g., oil and gas; Fig. 4). Driven by strong and growing global demand for fossil fuel resources (IEA, 2008) exploration is moving further offshore and toward greater depths. Many floating offshore oil platforms will be capable of drilling in water depths greater than $2300 \mathrm{~m}$, and some at more than $3300 \mathrm{~m}$ (IEA, 2008). Investment in deep-water drilling is expected to continue to grow; from $\$ 58$ billion in 2001-2005 to $\$ 108$ billion in 2008-2012, with $85 \%$ going to the "golden triangle" of North America, Brazil and West Africa, according to recent industry forecasts (IEA, 2008). The imminent expansion of mineral rights by countries to 30 million $\mathrm{km}^{2}$ of extended continental shelves (UNEP/GRID-Arendal, 2011) diminishes the likelihood of oil and gas extraction in areas beyond national jurisdiction. However, by bringing such activities together under existing national leasing and regulatory frameworks, the likelihood of interactions between oil and gas production and other users operating on and in the high seas (to which countries can make no extended claim) greatly increases. 


\subsection{Deep-seabed mining of mineral resources}

The International Seabed Authority has jurisdiction over mineral resource claims in "the Area" (i.e. the seabed and ocean floor and subsoil thereof beyond limits of national jurisdiction). The first applications for exploration by Pioneer Investors were filed with the precursor to the International Seabed Authority (the Preparatory Commission) in 1987. Between 1987 and 2009, only 10 such applications were filed. However, since 2010, a strong increase in applications has been seen, with 13 more being filed by 2013 (Fig. 4). The seven-fold increase in the rate of submission of exploration applications in the last four years (from 0.45 applications per year to 3.25 applications per year on average) has been driven by market forces (Papp et al., 2008), conflict in regions of terrestrial mining (Wilburn, 2011) and the promulgation of regulations allowing exploration to go ahead in these areas (ISA, 2012a).

The global market for cobalt is heavily reliant on supply from the Democratic Republic of Congo. Political instability in the Democratic Republic of Congo and its neighbors has led to a number of price spikes and breaks in supply in the past (Wilburn, 2011). This remains a salient concern as the Democratic Republic of Congo continues to supply approximately $50 \%$ of cobalt in a climate of rising demand (Wilburn, 2011). Uncertainty in the supply of cobalt is a major concern for a wide range of high-tech industries that require cobalt in their production processes (Cobalt Development Institute, 2013). Demand for cobalt has risen from approximately $40 \mathrm{kt}$ in 2001, to over $75 \mathrm{kt}$ in 2012 (Formation Metals, 2013). To meet rising demand, global production has increased to $110 \mathrm{kt}$ in 2013 (USGS, 2013) but stockpiling by China and continued concern over political instability and nationalization of terrestrial sources have caused the European Commission to name cobalt as a "Critical Raw Material" (EC, 2010). This has led to strong interest in exploitation of deep-sea deposits. Cobalt-rich ferromanganese crusts found on shallow seamounts contain an order of magnitude more cobalt than terrestrially mined ore (1.7\% vs. $0.1-0.2 \%$, respectively; Hein et al., 2013; ISA, 2008). Thus, the potential for seamounts to provide a substantial alternative source of cobalt is an active and ongoing discussion (ISA, 2012b).

In July 2012, the International Seabed Authority approved Regulations on Prospecting and Exploration for Cobalt-rich Ferromanganese Crusts in the Area (ISA, 2012b), paving the way for countries to apply for exploratory leases. Within a year of the International Seabed Authority approval of the regulations, three applications for exploratory leases were registered. Given the pull of increasing demand and the push of unstable terrestrial mining locations, deep-sea mining of cobalt-rich ferromanganese crusts is set to become a reality. Such deep-sea mining represents a burgeoning conflict of interest with deep-sea fisheries, scientific research and conservation interests. Both deep-sea fisheries and cobalt-rich crust mining are focused on shallow seamounts. The thickest and most cobalt-rich crusts are found from 800 to $2500 \mathrm{~m}$ depth, below oxygen minimum zones (mostly in the Pacific; Hein et al., 2013). As noted in Section 2.1, deep-sea fisheries are progressively fishing at deeper depths. In addition, scientists have noted with concern the overlap between mining interests and research focusing on deep-sea chemosynthetic vents and seep (Van Dover, 1995; Van Dover et al., 2011) and, as mentioned in Section 2.1, seamounts (Morato et al., 2010b).

The trend in applications for exploratory contracts indicates that companies around the world are actively considering mining in areas beyond national jurisdiction. Applications have been granted to 18 countries (including one application shared by 6 countries) for the exploration of three resources: polymetallic nodules, polymetallic sulphides and cobalt-rich crust, and as the first wave of exploratory contracts expire in 2016, further applications for exploitation are expected to be submitted in the near future (ISA, 2013). To understand the potential magnitude of deep-sea mining, a quick consideration of the area that may be vulnerable to extractive activities is useful. Each polymetallic nodule application identifies an area of up to $150,000 \mathrm{~km}^{2}$, and an area of equal size and value to be set aside for development by the Enterprise (i.e. intended to serve as the ISA's own mining operator, not currently set-up) or developing countries. Over a period of 8 years, the application size is reduced to no more than $75,000 \mathrm{~km}^{2}$. This has generally resulted in exploratory claims and reserved areas of just under $75,000 \mathrm{~km}^{2}$ each. Fifteen applications for exploratory contracts have been made with 3 put forward by developing countries to utilize reserved areas. Together with two further manganese nodule mining claims staked independently of the International Seabed Authority by Ocean Minerals Company of the United States (also around 150,000 $\mathrm{km}^{2}$ each), 5 polymetallic sulphide applications $\left(10,000 \mathrm{~km}^{2}\right.$ each) and 3 cobalt-rich crust applications (totaling $12,000 \mathrm{~km}^{2}$ ), it is likely that over 2 million $\mathrm{km}^{2}$ of the Area (or approx. $1 \%$ ) is already potentially subject to deep-sea mining (ISA, 2008, 2012b).

\subsection{Scientific research and marine genetic resources in areas beyond national jurisdiction}

\subsubsection{Discovery and description of new deep-sea species}

Science is an increasingly relevant stakeholder in the deep oceans, both within and beyond the EEZs of countries (e.g., Godet et al., 2011). As previously indicated by Ramirez-Llodra et al. (2010), the trend in the discovery rate of new nematode species in the deep seas (approximately 50\% of known species have been described in the last 20 years) and the trend in the cumulative description rate of crustacean species in the deep seas (around $40 \%$ have been described in the last 20 years; Ramirez-Llodra et al., 2010; Godet et al., 2011; Fig. 2) exhibit strong growth. The rapid and recent expansion of scientific activities in the deep sea has been enabled by technological developments such as autonomous underwater vehicles and more traditional remotely operated vehicles and deep-water manned submarines (Bachmayer et al., 1998). Research on marine geo-engineering such as iron fertilization, which has already occurred to a limited degree (Galaz, 2012), represents another scientific pursuit in areas beyond national jurisdiction potentially with profound ramifications which will be discussed below.

\subsubsection{Bio-prospecting for marine genetic resources}

Scientific research also supports the potential discovery of vast amounts of novel biomaterials that may be useful to the pharmaceutical, industrial, and biotechnology industries (Cowan, 1997; Glowka, 1999). Extreme temperatures, pressure and chemical composition of the waters surrounding hydrothermal vents in the deep sea result in unique biochemical pathways wellsuited for a host of industrial uses that require thermo- and barostable compounds or enzymes (Arrieta et al., 2010; Leary et al., 2009). These compounds have uses in industries as diverse as the food industry, production of biofuels and biopharmaceuticals (Ramirez-Llodra et al., 2011). Such bio-prospecting for marine genetic resources has raised concerns over access and benefit sharing of genetic resources in areas beyond national jurisdiction. Only nations with well-developed research infrastructure will be able to fully realize potential gains from marine genetic resources in areas beyond national jurisdiction as they have the technical capabilities to access these potentially deep and distant resources. Although it has not been possible to identify gene patents from organisms located solely in areas beyond national jurisdiction, examination of all marine gene patent claims reveals that 10 countries account for the vast majority (>90\%) of claims, with 3 


\section{Cable faults by cause (\%)}

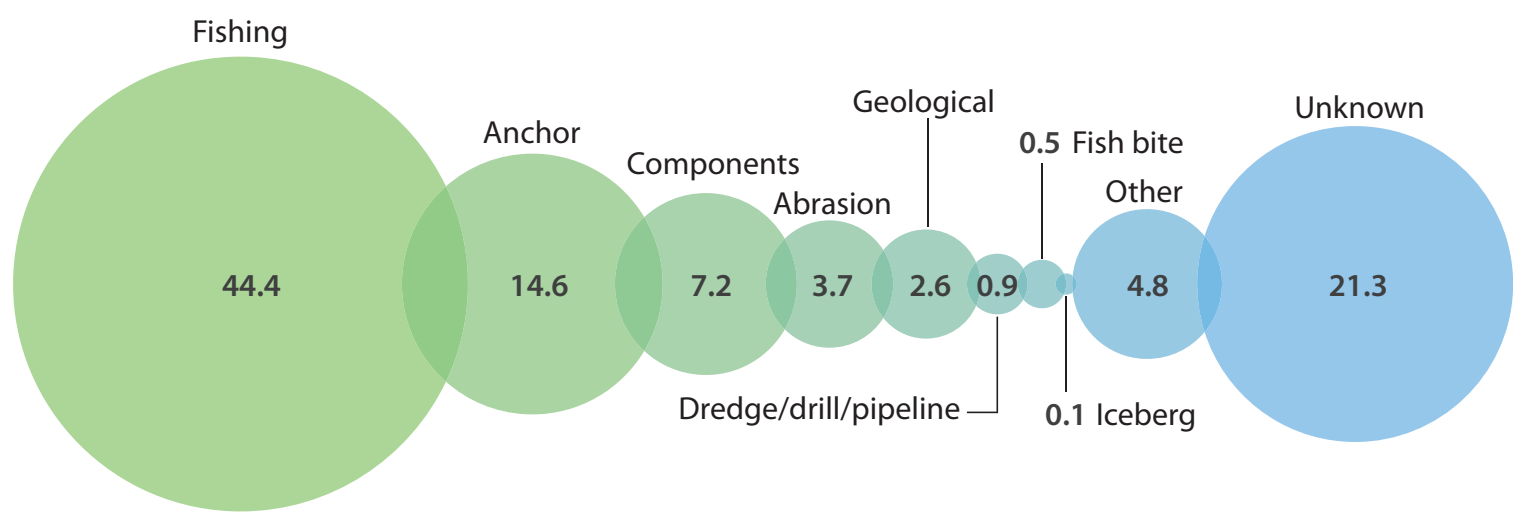

Fig. 3. Proportion of cable faults by cause, from 1959 to $2006(n=2162)$.

Adapted from Carter et al. (2009).

countries (USA, Germany, Japan) submitting 70\% of claims (Ramirez-Llodra et al., 2011). The trend in human use for all marine genetic resources (within territorial seas, Exclusive Economic Zones, continental shelves and areas beyond national jurisdiction) reveals a clear pattern of increasing use, with $95 \%$ of patent claims for marine genetic resources having been filed after 2000 (Arnaud-Haond et al., 2011). It is estimated that the number of marine genetic resources patents is increasing at $4 \%$ per year, while the number of marine species with patented genes is growing at $12 \%$ per year (Arrieta et al., 2010).

\subsection{Submarine cables}

The laying of submarine cables is a non-negligible use of the ocean floor and they span vast areas of the global ocean, including areas beyond national jurisdiction. Their increasing use is driven by growing global demand for Internet bandwidth. "Lit" cable capacity doubled between 2000 and 2002, doubled again between 2002 and 2007, and since then has increased at an even more elevated rate, almost tripling between 2007 and 2012 (Telegeography, 2013). Demand is expected to continue growing (from less than 50 terabits per second in 2011 to more than 150 terabits per second in 2018; Telegeography, 2013). This development should drive the laying of new submarine fiber-optic cables. Fig. 3 shows the proportion of cable faults that occurred due to different causes between 1959 and 2006. The figure illustrates the potential risk of more users operating in areas beyond national jurisdiction. This is particularly the case for fishing activities, which were responsible for $44.4 \%$ of the reported cable faults. The addition of more users of the global marine commons along with a rise in the number and size (both in terms of length and capacity) of submarine cables can be expected to increase the probability of interactions between users and cause damage to cable lines, although this is not currently a significant problem (Takei, 2012).

\subsection{Global trade and maritime shipping}

The International Maritime Organization forecasts a strong expansion of maritime global trade (IMO, 2012). This increase in trade combined with the continued globalization of corporate supply chains is impacting maritime shipping. Global merchandize trade took off in the 1950s supported by the advent of containerization (The Economist, 2013; Fig. 2). The next 40 years saw a steady increase of approximately 15 million tons per year. The last decade, however, has seen average growth rates more than quadruple to 70 million tons per year, adding over 700 million tons over ten years (The Economist, 2013; Fig. 2). Despite the recent global economic downturn there are no indications that this trend is slowing down. Given the increase in predicted volume of merchandize trade and the associated increase in maritime shipping, it can be expected that shipping will continue to use more of the global oceans as existing, established maritime trade routes become more crowded (primarily in coastal areas but this may also affect to a lesser extent areas beyond national jurisdiction) and new markets open and expand. This sets up further potential for interactions between different users of areas beyond national jurisdiction and tradeoffs in the expression of their customary rights to use ocean space.

\subsection{A summary of trends - users on the doorstep of areas beyond national jurisdiction}

Resources in areas beyond national jurisdiction are becoming increasingly attractive to a diverse set of users. As the number of users and their cumulative impact increases, so too will the demand for effective and adaptive governance mechanisms. Even relatively stable and well-established user groups such as fisheries continue to challenge existing institutions. The increase in the number of countries involved in fisheries illustrates the changing political context of such activities. A number of other industries (e.g., those involved in deep-sea mining) are rapidly increasing their interest in areas beyond national jurisdiction, and the rate of change in these sectors far outpaces that of fisheries. The recent rapid increases in submarine cable capacity, applications for exploratory contracts registered with the International Seabed Authority, merchant shipping (connected to trends in global merchandize trade), the discovery of new species, and the depth of both oil and gas exploration and production indicate a number of interesting trends of relevance for areas beyond national jurisdiction (Fig. 4).

\section{Shifting dynamics in areas beyond national jurisdiction}

Beyond these relatively well-established user groups, and the use trends described, it is also important to consider other users or more surprising dynamics. Given the limitations of the planetary capacity to provide goods and services (Rockström et al., 2009), and the risk of non-linear change resulting from human activities (Scheffer et al., 2001), we argue that it is necessary to actively anticipate surprise and build flexibility into existing governance frameworks. Current assumptions about the future behavior of actors and the impacts of technological development are constrained by a linear, 'business as usual' type of thinking. The contribution of this manuscript is to consider and account for the 


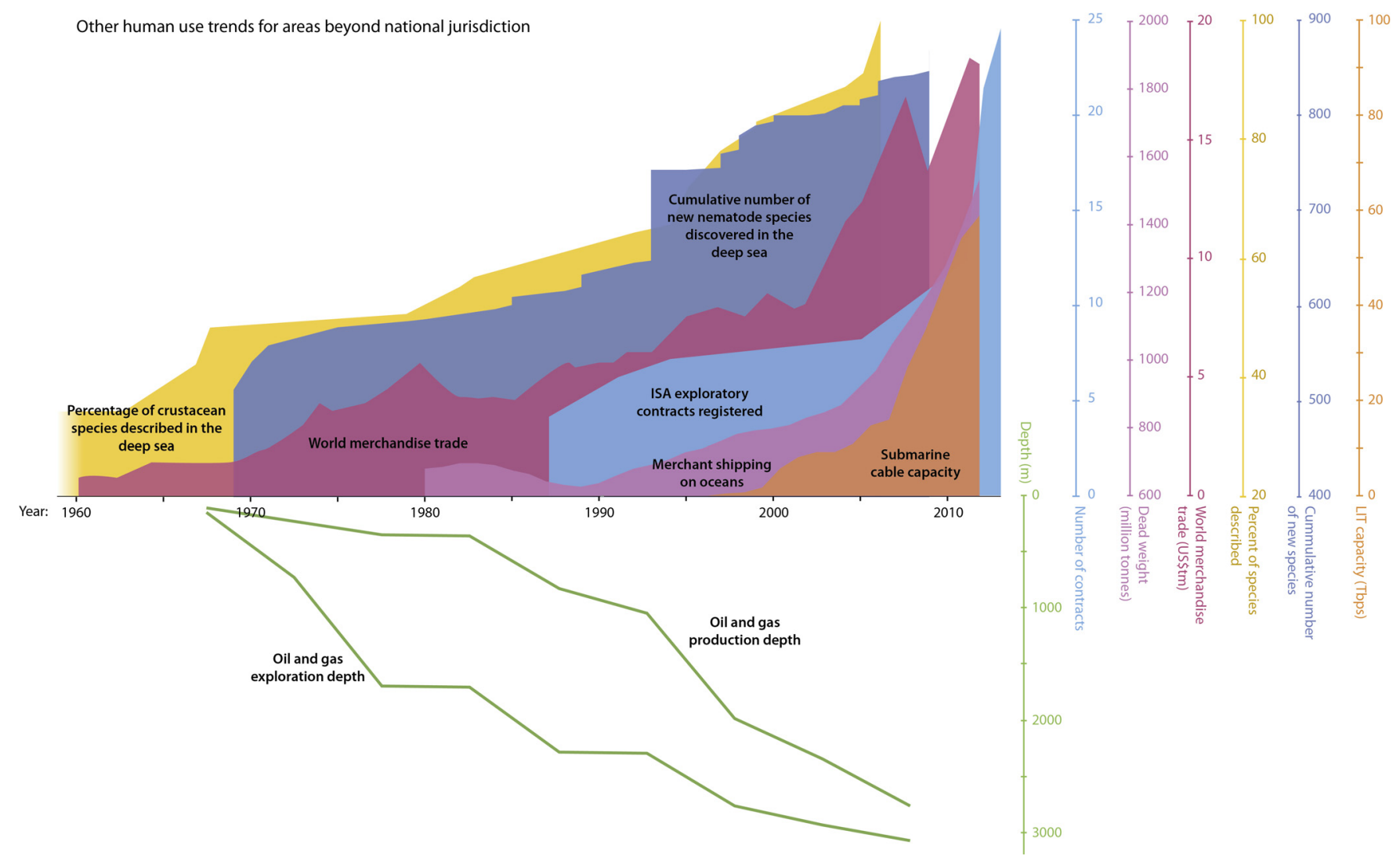

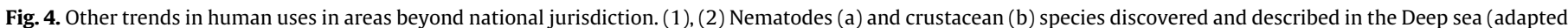

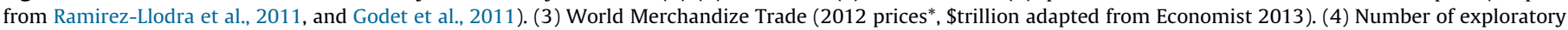

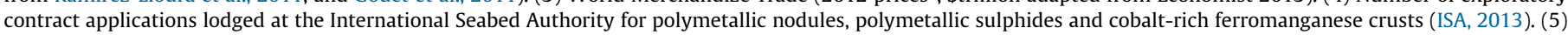

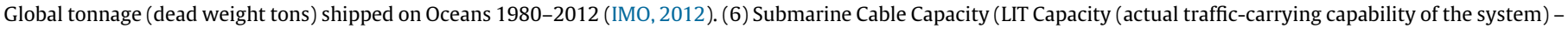
Terabits per second). Adapted from Telegeography (2013). (7), (8) Maximum water depth of Oil Exploration (in meters) and of Oil Production (in meters).

Adapted from World Energy Outlook, IEA (2008).

interaction between surprise and governance rather than replicating the excellent scholarship that puts forward ideal principles for governance of areas beyond national jurisdiction based on perceived limitations and 'gaps' in current regimes (Gjerde et al., 2008; de la Fayette, 2009; Oude Elferink, 2012).

We define surprise following Galaz et al. (2011); that is, situations in which the behavior in a system, or across systems, differs qualitatively from expectations. Surprise as presented here (and in Galaz et al., 2011) draws on a long tradition of scholarship on unexpected futures from the crisis management and organizational theory literature (DuBrin, 2013). One recent contribution has drawn on the fractal mathematics of Mandelbrot to provide a new way of thinking about unexpected events and the nature of change in the 21st century. Topper and Lagadec (2013) present a framework for addressing extreme uncertainty and turbulence (Folke and Rockström, 2009) that they argue is able to take advantage of the "crucial advance offered by fractal theory ... to envision, capture and handle very unstable, blurred and hypercomplex states of the world" (Topper and Lagadec, 2013; 15). Rittel and Webber (1973) previously articulated this perspective through the concept of 'wicked problems' in which they argue that the vast majority of strategies and tools we have developed to deal with 'normal problems' are completely unable to help us address 'wicked' problems.

Another avenue in the literature that provides a valuable perspective on unexpected dynamics is Helbing (2013) which focuses on the impact of globalization and technology in creating and strengthening globe spanning, hyper-connected and interdependent networks. For example, he illustrates the interconnections between financial risks and instabilities such as asset price collapses and extreme volatility of the price of commodities to, global governance failures such as illicit trade, organized crime and corruption. Helbing (2013) presents a framework for considering the inter-relations and systemic risks and uncertainties that result from networked, complex interaction of "Economic Risks, Geopolitical Risks, Environmental Risks, Societal Risks and Technological Risks" (Helbing, 2013).

For the purposes of this review, we choose to use the framework provided by a leading thinker in the area of crisis management and organizational theory, La Porte and Consolini (1991) and La Porte (1996, 1999, 2006, 2007a,b). One method to clearly describe and distinguish unexpected dynamics is to identify different categories of existing dynamics. La Porte (2007b) presents unexpected dynamics categorized as either; 'slow burning emergencies' (La Porte, 2007b) where both slow and rapid change are not completely unexpected and some form of governance structure exists to respond to it; or 'rude surprises' where often no governance structure is in place and behaviors differ significantly from expectations resulting in genuinely unexpected surprises (Galaz et al., 2011). The first category represents relatively expected dynamics that existing institutions would likely be able to address, whereas the latter category represent highly unexpected dynamics beyond the adaptation and coping capacity of existing institutions or emerging in a spatiotemporal location where no legitimate governance institution is in place at all. The 'slow burning emergencies' and 'rude surprises' presented below which are tethered to our analysis of human use trends in areas beyond national jurisdiction are a non-exhaustive list of potential 
surprises and the emergence of surprising situations related to human uses of these areas.

\subsection{Slow burning emergencies - the prospects for an oceanic gold rush}

The first level of surprise dynamic occurs where fragmented and insufficient regulation in the high seas creates a "gold rush" effect, where resource users are able to make large investments in technology and exploit resources before governance institutions can react. Such "roving bandit" behavior (cf. Berkes et al., 2006), where, actors are able to take advantage of legal loopholes, has been observed in high seas fishing activities (Österblom and Sumaila, 2011) and is likely to occur also in other sectors engaged in high seas resource extraction/uses. Such "first movers" have clear advantages when extracting newly discovered resources in the high seas.

\subsubsection{Fishing for gold in the oceans}

The New Zealand and Australian Orange roughy (Hoplostethus atlanticus) deep-sea fishery illustrates how a technologically advanced fishing industry can quickly exploit a newly discovered resource in the face of lagging governance and limited biological knowledge. Earlier developments in deep-sea trawling technology enabled intensive exploitation of newly discovered deep-sea stocks; specifically substantial deep-sea technology was developed by the fishing fleets of the Soviet Union (Sealy, 1974). This resulted in the collapse of several orange roughy stocks prior to the development of effective management measures (Clark, 2001). Another example of potential gold rush effect and the first mover advantage from fisheries is the recent emergence of mesopelagic myctophid fisheries (primarily for animal feed and represented by around 250 species known as "lanternfishes"). These fisheries represent a new frontier where exploitation may again occur before the basic biology of the target species, implications for nontarget species and ecological interactions are understood (Catul et al., 2011).

Further surprises in fisheries in areas beyond national jurisdiction include the rapid development of illegal, unreported and unregulated fishing for toothfish (Dissostichus spp.) in the Southern Ocean (Österblom and Sumaila, 2011) and the recently described scale of Chinese distant water fisheries (Pauly et al., 2013). Difficulties in monitoring and enforcement in the high seas, combined with the use of flags of convenience and legally questionable, or explicitly illegal activities (Agnew et al., 2009; Gianni and Simpson, 2005; Sumaila et al., 2006; Österblom et al., 2011; Österblom and Sumaila, 2011) complicates enforcement. Trends in illegal activities are naturally difficult to obtain, but existing indications suggest declines of such fishing in areas of well-functioning governance (Agnew et al., 2009; Österblom and Sumaila, 2011), but remain large challenges in areas with less well functioning governance (Agnew et al., 2009). Given prior experience with rapidly developing fisheries in the high seas and the close association between illegal, unreported and unregulated fishing and limited governance (Agnew et al., 2009; Österblom and Sumaila, 2011), such activities are expected to occur and represent limited surprise. Despite the challenges associated with governance of such rapidly developing dynamics, there is a general preparedness for addressing these fisheries gold rush dynamics in the international community (Österblom, in press) and increasing potential in global governance frameworks (Flothmann et al., 2010).

\subsubsection{Mining the seafloor for 'gold'}

Gold rush effects are not limited to fisheries. Rapidly rising demand for high tech products which require cobalt, e.g., solar panels, smartphones and tablets, combined with uncertainty in the terrestrial supply (Dredging Today, 2013) may substantially increase economic gains for extraction in the high seas. A breakthrough in autonomous mining robots or marine remote operated vehicles could quickly shift the economics of deepseabed mining and lead to rapid expansion of mining activities. Recent developments indicate that such technological breakthrough may be imminent: Nautilus Minerals, a company seeking to mine hydrothermal vents in the deep ocean, has developed a 310-ton robotic mining vehicle that will operate at 1600 meters depth off the coast of Papua New Guinea (Dredging Today, 2013).

While deep-sea mining is one of the few instances where management regulations have been put in place before extraction activities begin (through the International Seabed Authority), goldrush dynamics are still feasible through gaps in regulation due to lack of sufficient knowledge about ecosystem functioning and knowledge or regulation of the potential impacts of the industry on the environment. Such is the case with mining of deep-sea ecosystems: some of these ecosystems have developed over thousands of years and we have little to no knowledge of how the biology and ecology of such systems will be impacted by mining (Van Dover, 1995; Van Dover et al., 2011). In addition, it can be argued that if there were to be a prolonged and severe shortage in terrestrial sources of highly sought after minerals such as cobalt, then the Parties to the International Seabed Authority may come under pressure from industry to relax regulations thus allowing a gold rush scenario to emerge.

One complication with the existing governance structure, despite its relative strength compared to other sectors, is the issue of sponsoring states of convenience. Under the United Nations Convention on the Law of the Sea (UN LOSC, 1982), private companies can only carry out mining activities in the Area when they are sponsored by a State that is a party to the Convention. The absence of strict requirements for sponsoring States of companies that mine in areas beyond national jurisdiction may lead to the development of "sponsoring States of convenience". This language refers to the phenomenon of flags of convenience in the fishing and merchant shipping sectors, where States grant their flag to merchant ships and/or fishing vessels even though they do not have the capacity or willingness to enforce international regulations. This represents a significant risk-management challenge as the dynamics that drive the development of deep sea mining could be more difficult to govern when combined with this potential phenomenon of "sponsoring states of convenience" despite a governance regime already being in place.

\subsubsection{Prospecting for genetic 'gold'}

Unlike fisheries and seabed mining, no international agreements exist specifically to regulate the identification, isolation or patenting of marine genetic resources from areas beyond national jurisdiction (Arnaud-Haond et al., 2011), nor has it been determined what type of access regime will be implemented. Developing countries have expressed that the existing regime of (unregulated) high seas freedom is highly unequal and have advocated for equitable access and benefit sharing of marine genetic resources, referring to the common heritage concept that is already applicable to mining in areas beyond national jurisdiction (Salpin and Germani, 2007; Leary et al., 2009). Until such an access and benefit sharing agreement is in place, biotechnology corporations will be free to exploit this lack of governance for their own benefit. The emergence of bioprospecting for marine genetic resources was highly surprising, but due to the lack of an immediate and clear consequence for biodiversity and ongoing efforts by governance institutions to begin to address the issue (Gjerde, 2008), it can no longer be considered as high-surprise. 


\subsubsection{Black gold in the deep seas}

Oil and gas resources are likely to occur mostly in the continental shelf of coastal States and thus under their jurisdiction. The definition of the continental shelf as contained in the Law of the Sea Convention (UN LOSC, 1982) was specifically designed to achieve that result. Current claims for extended continental shelves (out to a maximum of either 350 nautical miles from shore or 100 nautical miles beyond the $2500-\mathrm{m}$ isobath) expand national jurisdiction over seabed resources by more than 30 million $\mathrm{km}^{2}$. This adds a level of complexity to governance of the high seas overlaying such extended continental shelves, as activities on the continental shelf may have trans-boundary impacts. The surprise element with respect to oil and gas is twofold. Firstly, the move out to the edges of continental shelves may cause increasing levels of conflict between nations and with other user groups (e.g., deep-sea fisheries in the high seas that will be fishing on the same continental shelf but who will not fall under the national jurisdiction of the coastal state). It is even possible that conflict between the oil and gas and fishing or mining sectors may be greater in the deep oceans than in coastal areas due to differences in drilling methods used at different depths. For example, the world's deepest offshore drilling and production platform (2450 m), has a central pillar or 'spar', which is connected to 22 wells operating on the sea floor and the oil is brought to the surface via powerful pumps also in place on the seafloor (Royal Dutch Shell, 2013) This platform, with its distributed well and pump system differs from more traditional coastal production platforms which go straight down to the seafloor (i.e., they have only one centralized well and thus cover a smaller area of the seafloor with drilling equipment). Trawling or mining in an area around a deep-sea platform would be extremely risky relative to most coastal oil and gas platforms. Secondly, the possibility of a blowout in areas beyond national jurisdiction similar to the failure of the Deep-water Horizon deep-sea oil rig (at the time one of the deepest operating platforms in the world; Houck, 2010) raises the issue of how a disaster of such magnitude could be dealt with in areas beyond national jurisdiction. A key concern in such a scenario is benefit and burden sharing. Attempts have been made to clarify responsibility through the Seabed Disputes Chamber of the International Tribunal for the Law of the Sea (acting in an advisory capacity): "Taking into account that, as shown above in paragraph 203, situations may arise where a contractor does not meet its liability in full while the sponsoring State is not liable under article 139, paragraph 2, of the Convention, the Authority may wish to consider the establishment of a trust fund to compensate for the damage not covered" (ITLOS, 2011).

Despite these attempts, it remains unclear how such a scenario would play out in practice and how the different responsible entities would interpret international law in order to reduce their culpability by placing the burden on other actors. This is perhaps not so different to what occurs in coastal areas but given the technological challenges and vast expense of responding to a disaster in an area abutting areas beyond national jurisdiction, these complications and uncertainties become even more problematic. Another consideration is that there are active mining claims by a country that is not a party to the International Seabed Authority (i.e., the US), leaving open the possibility that similar oil and gas claims might be made entirely outside of the competence of the current regulatory regime.

\subsection{Rude surprises - entirely new groups of users}

The above examples illustrate that governing institutions necessarily need to combine crisis preparedness and response capabilities in order to maintain and develop their adaptive capacity (Galaz et al., 2011; Österblom and Sumaila, 2011).
However, the examples below illustrate the necessity to be prepared for genuine 'rude surprises' (La Porte, 2007b), where completely unexpected, highly unlikely and largely unforeseen challenges may develop, potentially within a governance vacuum (Carpenter et al., 2009).

\subsubsection{Ocean geo-engineering - expected but with a high potential for surprise}

The potential use of ocean geo-engineering to combat climate change and ocean acidification through, inter alia, the sequestration of atmospheric $\mathrm{CO}_{2}$ is becoming established in the academic discourse (Galaz, 2012; Barry et al., 2013) and policy debates (CBD, 2012b; Gjerde, 2008). A number of different ways of geoengineering the climate utilizing the oceans have been suggested, examples include:

- Deep-sea Carbon Sequestration: the possibility of directly injecting $\mathrm{CO}_{2}$ into the deep-sea or beneath the seabed has been around for half a century now (Marchetti, 1977), though the ecological risks associated with this activity (Barry et al., 2013) have so far outweighed perceived benefits.

- Ocean Fertilization: either direct fertilization through the addition of nutrients such as iron directly to the ocean or via upwelling modification to bring existing nutrients to the surface. The intention is to directly stimulate primary productivity in the ocean and hence $\mathrm{CO}_{2}$ uptake (CBD, 2012b).

- Enhanced Ocean Alkalinity: this would be achieved via adding alkaline minerals in order to chemically augment the ability of the ocean to store $\mathrm{CO}_{2}$. This process has the additional potential impact of buffering the ocean to processes of acidification through altering the $\mathrm{pH}$ level (CBD, 2012b).

- Ocean Biomass Storage: the direct deposit of crop waste or other terrestrial biomass onto the deep ocean seabed (CBD, 2012b).

There has already been a move to block iron fertilization of the ocean on a large scale under the auspices of the London Convention (1972). This convention concerns "the prevention of marine pollution by dumping of waste and other matter". In March 2010, the governing body of the London Convention endorsed, on a unanimous basis, a scientific statement of concern on ocean fertilization. The body went even further and declared that large scale iron fertilization schemes are "currently not justified". The Convention intends to develop regulations to oversee such activities and has adopted a regulatory framework that only allows iron fertilization as part of "legitimate scientific research". While iron fertilization has been considered in depth by the London Convention, regulation of other forms of marine geoengineering are only beginning to be considered as a result of a recent amendment to the London Convention adopted in October 2013 (London Convention, 1972). Although the Convention on Biological Diversity is monitoring developments in geo-engineering, it has no management authority and its role in areas beyond national jurisdiction has been limited to the provision of scientific and, as appropriate, technical information and advice relating to marine biological diversity to competent authorities (e.g., the United Nations General Assembly, 1974; Dunn et al., in press).

Thus, geo-engineering holds the possibility for real surprise if a State or an entity acting under its jurisdiction, (e.g., a multinational corporation) chooses to experiment on a large scale within existing governance loopholes. Such action, at small scale and in contravention to the law (although not in areas beyond national jurisdiction) has already taken place. Planktos, a Silicon Valley start-up, was the source of recent controversy when in 2010 it dumped around 100 tons of iron sulphate into the Pacific as part of an ocean fertilization geo engineering scheme (Deep Sea News, 
2012). The combination of uncertainty about both governance of areas beyond national jurisdiction and governance of geoengineering ensures this potential use could generate significant surprise.

\subsubsection{A future of inhabiting areas beyond national jurisdiction?}

Just as Jules Verne predicted the advent of submarines and other technologies a century before they became a reality (Verne, 1870), science fiction today offers visions that contribute to an understanding of how new users may utilize areas beyond national jurisdiction. Current visions include self-reliant communities living outside national jurisdiction, independent of ethical constraints of traditional societies. While such a scenario seems farfetched, the strong draw of no taxes and a very limited set of regulations, combined with a fundamental questioning of the legitimacy of the international order based on nation-states has already propelled work toward such communities in areas beyond national jurisdiction (e.g. http://www.seasteading.org). Hence, despite the existence of rules of international law regulating jurisdiction of States over such entities and its inhabitants, there is a growing interest in exploring new ways of living in areas beyond national jurisdiction. Given that the goal of the sea-steading movement (the current frontrunner in any attempt to inhabit the ocean) is to pursue a libertarian dream of "unprecedented personal freedom", it is unclear how such 'frontier communities' would respond to governance of areas beyond national jurisdiction, including issues related to access and benefit sharing, the common heritage of mankind, regulations regarding dumping, and fishing quotas administered by regional fisheries management organizations. Although this scenario represents a low-probability risk, rejection of such governance regimes and/or customary international law by a permanent community in areas beyond national jurisdiction would represent a novel challenge to governance and very much a rude surprise.

\section{Strategies and tools for governing the unexpected}

In this paper we have set out to describe quantitative trends in human use of areas beyond national jurisdiction and potential unexpected dynamics that may arise in the future. An in-depth analysis of the current and emerging governance regime for areas beyond national jurisdiction with respect to how it may or may not be able to deal with slow burning emergencies and rude surprises is beyond the scope of this paper. However, it is worth considering what the organizational theory and crisis management literature has to contribute with respect to managing uncertainty and in providing institutional design rules well-suited for recognizing and responding to unexpected dynamics. Below we aim to provide a perspective on what complexity means for thinking about future governance of the oceans through the lens of trends in uses and scenarios of future use of areas beyond national jurisdiction.

The work of La Porte (1996, 2006, 2007a,b) also provides insight into what kinds of governance institutions might be required in order to be able to respond in the event of "rude surprises." However it is noted that there will always need to be trade-offs between designing an institution to be able to deal with "rude surprises" versus designing institutions for efficient functioning under 'normal' conditions of operation and in the context of "slow burning emergency" situations. In the words of La Porte "to remain on the coherent side of chaos" (La Porte, 2007b) requires the capacity and indeed authority to be able to breakdown, reorganize and recombine "organizational capacities" in a way that is able to respond to novel and previously unknowable problems while putting in place systems that are able to learn and incorporate new problem domains into the DNA of the institution (La Porte, 2006, 2007b).
An example in the marine governance realm of the presence of critical organizational capacities to respond to environmental challenges can be found in Bodin and Österblom (2013). This study, which focuses on efforts to address illegal fishing in the Southern Ocean, indicates that a number of organizational capacities might be particularly important including; access to advanced technology, the presence of significant political contacts and involvement in public awareness campaigns aimed at drawing attention to illegal fishing. The key here is that these capacities are flexible and embedded within networks. No single organization can possess the required organizational capacities to respond to the challenge of illegal fishing.

In contradistinction to "slow burning emergencies", "rude surprises", by their very nature, cannot be wholly anticipated or predicted and as such the focus must be on design principles for rapid response and evolution of a given governance organization. With respect to governance of areas beyond national jurisdiction, "rude surprises" or the emergence of "slow burning emergencies" may not even be detectable due to the absence of a competent institution or, an organization may possess limited resources, and/ or a strictly defined mandate. In such circumstances, it is possible for a situation to emerge before governance organizations recognize it and are able to develop capacity to respond (Galaz et al., 2011).

As well as responding to surprise, the introduction of systematic scenario planning (Schwartz, 1998, Swart et al., 2004) and horizon scanning processes (Amanatidou et al., 2012) involving all user groups could prove useful in mapping out possible future trajectories in an attempt to plan and allocate resources to address possible future changes in the best way possible as well as informing the kinds of institutional designs that may be able to address different categories of both slow and rapid change. Today, there is no systematic attention on the rapidly evolving alternate futures of areas beyond national jurisdiction. A related approach outlined in Haasnoot et al. (2013) focuses on incorporating strategic future visioning and adaptive techniques into a planning process. This system is described as the "Dynamic Adaptive Policy Pathways" approach and can provide useful guidance for how to think about and plan for uncertainty dynamics in ocean areas beyond national jurisdiction.

The literature on "High Reliability Organizations" and "High Reliability Management" (Roe and Schulman, 2008) can also provide valuable insights when thinking about design principles for organizations and institutions that need to deal with different types of unexpected dynamics. Weick and Sutcliffe (2001) define High Reliability Organizations as an organization that has succeeded in avoiding catastrophes in an environment where normal accidents can be expected due to risk factors and complexity. In turn, they identify five characteristics of High Reliability Organizations that enable them to be highly effective and reliable when facing the unexpected: A preoccupation with failure, a reluctance to simplify interpretations, sensitivity to operations, a commitment to resilience and deference to expertise. Although not directly translatable, these five characteristics should be incorporated into a set of design principles for dealing with the consequences of globalisation and hyper-connectivity for governance of marine areas beyond national jurisdiction. Ultimately, the ability to 'embrace surprise' (La Porte, 2007a,b) requires the emergence of fundamentally transformative governance institutions (Olsson and Galaz, 2012).

\section{Conclusion}

Trends and potential surprise in relation to the exploitation of marine living and non-living resources have served as examples of 
present and potential shifts in human uses of areas beyond national jurisdiction. We have illustrated how fisheries, which traditionally could operate relatively unconstrained in these areas, will increasingly, share this space with other users. Increasing diversity of users in traditional human uses, along with rising rates of development in many industries and the potential for the emergence of entirely new user groups represent major challenges to existing governance regimes. Solutions to these issues will be the product of increased interdisciplinary dialog and cooperation between academia, the policy community and the private sector, aimed at the development of comprehensive future scenarios including consideration of conflicting needs and cumulative impacts. Such collaborative investigations of innovative policy measures for areas beyond national jurisdiction for example the rights based fisheries approach of Hannesson (2011), are necessary to develop flexible, adaptive governance systems capable of sustainably managing expanding existing uses and anticipating and responding to unexpected dynamics whether they be slow burning emergencies or rude surprises. Finally, it is not surprising that attempting to articulate, define, and respond to various kinds of unexpected dynamics whether they be slow burning emergencies or rude surprises is extremely challenging. Recognizing the obstacles to governing the interacting challenges of our global environment and the naturalness of surprise and unpredictability is only a first step but it is a critical one and should inform future research on governance of marine social-ecological systems beyond national jurisdiction in the Anthropocene.

\section{Acknowledgements}

The Nippon Foundation-University of British Columbia Nereus program is a collaborative initiative by the Nippon Foundation, the Stockholm Resilience Centre, Duke University, the University of British Columbia, and three additional partners. The present article is a product of Nereus' international and interdisciplinary effort toward global sustainable fisheries. This research was also supported by MISTRA (the Swedish Foundation for Strategic Research), through a core grant to the Stockholm Resilience Centre at Stockholm University. We would like to extend a special thanks to Jeff Ardron for his constructive comments on an earlier version of this manuscript. Our thanks also go out to the two anonymous reviewers, especially the first reviewer whose insightful comments assisted us to markedly improve the manuscript and tell a clearer and more focused story. We express gratitude to Jerker Lokrantz of Azote for the graphic design of the figures and to Matilda Petersson for proofreading. Finally, we would like to express our gratitude to Dr. Dirk Zeller and Dr. Daniel Pauly of the University of British Columbia Sea Around Us Project for their provision of fisheries data.

\section{References}

Agnew, D.J., Pearce, J., Pramod, G., Peatman, T., Watson, R., Beddington, J.R., Pitcher T.J., 2009. Estimating the worldwide extent of illegal fishing. PLoS ONE 4 (2) e4570.

Amanatidou, E., Butter, M., Carabias, V., Könnölä, T., Leis, M., Saritas, O., SchaperRinkel, P., van Rij, V., 2012. On concepts and methods in horizon scanning: lessons from initiating policy dialogues on emerging issues. Sci. Public Policy 39, $208-221$.

Anonymous, 2013. Dredging Today: Bulk Cutter Arrives at Tyneside (UK). [press release] July 3rd, 2013; available at: http://www.dredgingtoday.com/2013/07/ 03/smd-bulk-cutter-arrives-at-tyneside-uk/ (accessed 12.09.13).

Arnaud-Haond, S., Arrieta, J.M., Duarte, C.M., 2011. Marine biodiversity and gene patents. Science 331 (6024) 1521-1522.

Arrieta, J.M., Arnaud-Haond, S., Duarte, C.M., 2010. What lies underneath: conserving the oceans' genetic resources. Proc. Natl. Acad. Sci. U.S.A. 107 (43) $18318-18324$
Bachmayer, R., Humphris, S., Fornari, D., Van Dover, C., Howland, J., Bowen, A., Elder, R.L., Crook, T. Gleason, D.E., Sellers, W.J., Lerner, S, 1998. Oceanographic research using remotely operated underwater robotic vehicles: exploration of hydrothermal vent sites on the Mid-Atlantic ridge at $37^{\circ}$ North $32^{\circ}$ West. Mar. Technol. Soc. J. 32 (3) 37-47.

Ban, N.C., Bax, N.J., Gjerde, K.M., Devillers, R., Dunn, D.C., Dunstan, P.K., Hobday, A.J., Maxwell, S.M., Kaplan, D.M., Pressey, R.L., Ardron, J.A., Game, E.T., Halpin, P.N., 2014. Systematic conservation planning: a better recipe for managing the high seas for biodiversity conservation and sustainable use. Conserv. Lett. 7, 41-54, http://dx.doi.org/10.1111/conl.12010.

Barbier, E.B., Moreno-Mateos, D., Rogers, A.D., Aronson, J., Pendleton, L., Danovaro, R., Henry, L., Morato, T., Ardron, J., Van Dover, C.L., 2014. Ecology: protect the deep sea. Nature 505, 475-476.

Barry, J.P., Buck, K.R., Lovera, C., Brewer, P.G., Seibel, B.A., Drazen, J.C., Tamburri, M.N., Whaling, P.J., Kuhnz, L., Pane, E., 2013. The response of abyssal organisms to low $\mathrm{pH}$ conditions during a series of $\mathrm{CO}_{2}$-release experiments simulating deep-sea carbon sequestration. Deep Sea Res. Part II 92, 249-260.

Bavinck, M., 2011. The Megaengineering of Ocean Fisheries: a century of expansion and rapidly closing frontiers. In: Brunn, S. (Ed.), Engineering Earth. Springer Science and Business Media, New York.

Berkes, F., Hughes, T.P., Steneck, R.S., Wilson, J.A., Bellwood, D.R., Crona, B., Folke, C., Gunderson, L.H., Leslie, H.M., Norberg, J., Nyström, M., Olsson, P., Österblom, H., Scheffer, M., Worm, B., 2006. Globalization, roving bandits, and marine resources. Science 311, 1557-1558.

Beveridge, M., Thilsted, S., Phillips, M., Metian, M., Troell, M., Hall, S., 2013. Meeting the food and nutrition needs of the poor: the role of fish and the opportunities and challenges emerging from the rise of aquaculture. J. Fish Biol. 83, 10671084.

Blight, L.K., Ainley, D.G., Ackley, S.F., Ballard, G., Ballerini, T., Brownell, R.L., Christina-Cheng, C.H., Chiantore, M., Costa, D., Coulter, M.C., Dayton, P., Devries, A.L. Dunbar, R., Earle, S., Eastman, J.T., Emslie, S.D., Evans, C.W., Garrott, R.A., Kim, S., Kooyman, G., Lescroël, A., Lizotte, M., Massaro, M., Olmastroni, S., Ponganis, P.J., Russell, J., Siniff, D.B., Smith Jr., W.O., Stewart, B.S., Stirling, I., Willis, J., Wilson, P., Woehler, E.J., 2010. Fishing for data in the Ross sea. Science 330 (6009) 1316

Bodin, Ö., Österblom, H., 2013. International fisheries regime effectiveness activities and resources of key actors in the southern ocean. Global Environ. Change 23, 948-956.

Boehlert, G.W., 1988. Current-topography interactions at mid-ocean seamounts and the impact on pelagic ecosystems. GeoJournal 16, 45-52.

Boehlert, G.W., Genin, A., 1987. A review of the effects of seamounts on biological processes. In: Keating, B., Fryer, P., Batiza, R., Boehlert, G. (Eds.), Seamounts, islands, and atolls. American Geophysical Union, Washington, DC.

Carpenter, S.R., Folke, C., Scheffer, M., Westley, F., 2009. Resilience: accounting for the noncomputable. Ecol. Soc. 14, 1-13.

Carter, L., Burnett, D., Drew, S., Marle, G., Hagadorn, L., Bartlett-McNeil, D., Irvine, D., 2009. Submarine Cables and the Oceans - Connecting the WorldIn: UNEPWCMC Biodiversity Series No. 31. ICPC/UNEP/UNEP-WCMC.

Catul, V., Gauns, M., Karuppasamy, P.K., 2011. A review of mesopelagic fishes belonging to family Myctophidae. Rev. Fish Biol. Fish. 21, 339-354.

Clark, M.R., 2001. Are deepwater fisheries sustainable? The example of orange roughy. Fish. Res. 51, 123-135.

Clark, M.R., Rowden, A.A., 2009. Effect of deepwater trawling on the macro-invertebrate assemblages of seamounts on the Chatham Rise, New Zealand. Deep Sea Res. Part I 56, 1540-1554.

Cobalt Development Institute (CDI), 2013. Cobalt Facts. Available at: http:// www.thecdi.com (accessed 12.09.13).

Convention on Biological Diversity (CBD), 2012a. Marine and coastal biodiversity: progress report on describing areas that meet the criteria for ecologically or biologically significant marine areas. UNEP/CBD/COP/11/22. Available at: http://www.cbd.int/doc/meetings/cop/cop-11/official (accessed 12.09.13).

Convention on Biological Diversity (CBD), 2012b. Geoengineering in Relation to the Convention on Biological Diversity: Technical and Regulatory Matters, Montreal, Technical Series No. 66152 p.

Available at: http://www.imo.org/About/Conventions/ListOfConventions/Pages/ Convention-on-the-Prevention-of-Marine-Pollution-by-Dumping-of-Wastesand-Other-Matter.aspx (accessed 18.02.13).

Cowan, D.A., 1997. The marine biosphere: a global resource for biotechnology. Mar. Biotechnol. 15, 129-131

de Forges, R., Koslow, J.A., Poore, G.C.B., 2000. Diversity and endemism of the benthic seamount fauna in the southwest pacific. Nature 405, 944-947.

de la Fayette, L.A., 2009. A new regime for the conservation and sustainable use of marine biodiversity and genetic resources beyond the Limits of National Jurisdiction. Int. J. Mar. Coastal Law 24, 221-280.

Deep Sea News, 2012. Available at: http://deepseanews.com/2012/10/here-we-goagain-with-dumping-iron-into-the-ocean/ (accessed 18.09.13).

DuBrin, A.J. (Ed.), 2013. Handbook of Research on Crisis Leadership in Organizations. Edward Elgar Publishing Limited, Cheltenham, UK.

Ardron, J., Ban, N.C., Bax, N.J., Bernal, P., Bograd, S., Corrigan, C., Dunstan, P., Game, E., Gjerde, K., Grantham, H., Halpin, P.N., Harrison, A.L., Hazen, E., Lagabrielle, E., Lascelles, B., Maxwell, S., McKenna, S., Nicol, S., Norse, E., Palacios, D., Reeve, L., Shillinger, G., Simard, F., Sink, K., Smith, F., Spadone, A., Würtz, M., 2011. In: Dunn, D.C. (Ed.), Ecologically or Biologically Significant Areas in the Pelagic Realm: Examples \& Guidelines - Workshop Report. IUCN, Gland, Switzerland.

Dunn, D.C., Ardron, J.M., Bax, N.J., Bernal, P., Cleary, J., Cresswell, I., Donnelly, B., Dunstan, P., Gjerde, K.M., Johnson, D., Kaschner, K., Lascelles, B., Rice, J., von Nordheim, H., Wood, L., Halpin, P.N., in press. The Convention on Biological 
Diversity's Ecologically or Biologically Significant Areas: origins, development, and current status. Mar. Policy. http://dx.doi.org/10.1016/j.marpol.2013.12.002 (in press).

European Commission (EC), 2010. Critical raw materials for the EU. Report of the Ad-hoc Working Group on defining critical raw materials $84 \mathrm{p}$.

Flothmann, S., von Kistowski, K., Dolan, E., Lee, E., Meere, F., Album, G., 2010. Closing loopholes: getting illegal fishing under control. Science 328 (5983) 1235-1236.

Formation Metals, 2013. Cobalt Fact Sheet 2013. Available at: http://www.formationmetals.com/i/pdf/factsheet_cobalt.pdf (accessed 25.09.13).

Folke, C., Rockström, J., 2009. Editorial: turbulent times. Global Environ. Change 19, $1-3$.

Galaz, V., 2012. Geo-engineering, governance, and social-ecological systems: critical issues and joint research needs. Ecol. Soc. 17 (1) 1-24.

Galaz, V., Moberg, F., Olsson, E.K., Paglia, E., Parker, C., 2011. Institutional and political leadership dimensions of cascading ecological crises. Public Adm. 89, 361-380.

Gianni, M., Simpson, W., 2005. The Changing Nature of High Seas Fishing: How Flags of Convenience Provide Cover for Illegal, Unreported and Unregulated Fishing. Australian Department of Agriculture Fisheries and Forestry, International Transport Workers' Federation, and WWF International. Available at: http:// www.wwf.org.uk/filelibrary/pdf/flagsofconvenience.pdf (accessed 12.09.13).

Gjerde, K.M., 2008. Options for Addressing Regulatory and Governance Gaps in the International Regime for the Conservation and Sustainable Use of Marine Biodiversity in Areas Beyond National Jurisdiction. IUCN Marine Law and Policy Paper No. 2 IUCN, Gland, Switzerland.

Gjerde, K.M., Dotinga, H., Hart, S., Molenaar, E., Rayfuse, R., Warner, R., 2008. Regulatory and Governance Gaps in the International Regime for the Conservation and Sustainable Use of Marine Biodiversity in Areas Beyond National Jurisdiction. IUCN, Gland, Switzerland.

Glowka, L., 1999. Genetic resources, marine scientific research and the international seabed area. Rev. Eur. Community Int. Environ. Law 8, 56-66.

Godet, L., Zelnio, K.A., Van Dover, C.L., 2011. Scientists as stakeholders in conservation of hydrothermal vents. Conserv. Biol. 25 (2) 214-222.

Goudey, C.A., January 2009. Innovation in high-seas aquaculture using aquaculture using mobile cages. Accenture Innovation Forum, Frankfurt, Germany. Available at: http://www.accenture.com/Microsites/innovation/forum2009/Documents/ Clifford_A_Goudey_Massachusetts_Institute_of_Technology.pdf (accessed 12.09.13)

Grotius, H., 1609. Mare Liberum - Mare Liberum, sive de jure quod Batavis competit ad Indicana tcommercia dissertation (latin) Lodewijk Elzevir.

Halpern, B.S., Walbridge, S., Selkoe, K.A., Kappel, C.V., Micheli, F., D’Agrosa, C., Bruno, J.F., Casey, K.S., Ebert, C., Fox, H.E., Fujita, R., Heinemann, D., Lenihan, H.S., Madin, E.M.P., Perry, M.T., Selig, E.R., Spalding, M., Steneck, R., Watson, R., 2008. A Global map of human impact on marine ecosystems. Science 319 (5865) 948952.

Hannesson, R., 2011. Rights based fishing on the high seas: is it possible? Mar. Policy 35 (5) 667-674.

Haasnoot, M., Kwakkel, J.H., Walker, W.E., ter Maat, J., 2013. Dynamic adaptive policy pathways: a method for crafting robust decisions for a deeply uncertain world. Global Environ. Change 23, 485-498

Hein, J.R., Mizell, K., Koschinsky, A., Conrad, T.A., 2013. Deep-ocean mineral deposits as a source of critical metals for high- and green-technology applications: comparison with land-based resources. Ore Geol. Rev. 51, 1-14.

Helbing, D., 2013. Globally networked risks and how to respond. Nature 497, 51-59.

Houck, O.A., 2010. Worst case and the deep-water horizon blowout: there ought to be a law. Tulane Environ. Law J. 24 (1) 1-18.

International Energy Agency (IEA), 2008. World Energy Outlook 2008. OECD/IEA, Paris, France. Available at: http://www.worldenergyoutlook.org/media/weowebsite/2008-1994/weo2008.pdf (accessed 12.09.13).

International Maritime Organisation (IMO), 2012. International shipping facts and figures: Information resources on trade, safety, security, environment. Available at: http://www.imo.org/KnowledgeCentre/ShipsAndShippingFactsAndFigures/ TheRoleandImportanceofInternationalShipping/Documents/International\%20Shipping\%20-\%20Facts\%20and\%20Figures.pdf (accessed 12.09.13).

International Seabed Authority (ISA), 2008. Cobalt-Rich Crust Mining Brochure/Fact Sheet. International Seabed Authority. Available at: http://www.isa.org.jm/ files/documents/EN/Brochures/ENG9.pdf (accessed 12.09.13).

International Seabed Authority (ISA), 2012a. Regulations on Prospecting and Exploration for Cobalt-rich Ferromanganese Crusts in the Area. ISBA/18/A/11 Annex International Seabed Authority, Kingston, Jamaica, pp. 48.

International Seabed Authority (ISA), 2012b. Decision of the Assembly of the International Seabed Authority relating to the Regulations on Prospecting and Exploration for Cobalt-rich Ferromanganese Crusts in the Area. ISBA/18/ A/11 International Seabed Authority. Available at: http://www.isa.org.jm/en/ sessions/2013/documents (accessed 12.09.13).

International Seabed Authority (ISA), 2013. Data aggregated from news reports on the ISA website. Available at: http://www.isa.org.jm/en/home (accessed 01.09.13).

ITLOS, Seabed Disputes Chamber of the International Tribunal for the Law of the Sea, Responsibilities and obligations of States sponsoring persons and entities with respect to activities in the Area. Advisory opinion of 1 February 2011, p. 205.

Klinger, D., Naylor, R., 2012. Searching for solutions in aquaculture: charting a sustainable course. Annu. Rev. Environ. Resour. 37, 247-276.

Koslow, J.A., Boehlert, G.W., Gordon, J.D.M., Haedrich, R.L., Lorance, P., Parin, N., 2000. Continental slope and deep-sea fisheries: implications for a fragile ecosystem. ICES J. Mar. Sci. 57, 548-557.
La Porte, T.R., Consolini, P.M., 1991. Working in practice but not in theory: theoretical challenges of "High-Reliability Organizations. J. Public Adm. Res. Theory 1, 19-48.

La Porte, T.R., 1996. High reliability organizations: unlikely, demanding and at risk. J. Conting. Crisis Manage. 4, 60-71.

La Porte, T.R., 1999. Contingencies and communications in cyberspace: the world wide web and non-hierarchical co-ordination. J. Conting. Crisis Manage. 7, 215224.

La Porte, T.R., 2006. Organizational strategies for complex system resilience, reliability and adaptation. In: Auerswald, P.E., Branscomb, L.M., La Porte, T.M. Michel-Kerjan, E.O. (Eds.), Seeds of Disaster, Roots of Response: How Private Action can Reduce Public Vulnerability. Cambridge University Press, Cambridge, UK.

La Porte, T.R., 2007a. Critical infrastructure in the face of a predatory future: preparing for untoward surprises. J. Conting. Crisis Manage. 15, 60-64.

La Porte, T.R., 2007b. Anticipating rude surprises - reflections on "Crisis Management" without end. In: Gibbons, D. (Ed.), Communicable Crises: Prevention, Response, and Recovery in the Global Arena. Information Age Publishing Charlotte, NC.

Leary, D., Vierros, M., Hamon, G., Arico, S., Monagle, C., 2009. Marine genetic resources: a review of scientific and commercial interest. Mar. Policy 33, 183-194.

Marchetti, C., 1977. On geoengineering and the $\mathrm{CO}_{2}$ problem. Climate Change 1, 5969.

Morato, T., Hoyle, S.D., Allain, V., Nicol, S.J., 2010a. Seamounts are hotspots of pelagic biodiversity in the open ocean. Proc. Natl. Acad. Sci. U.S.A. 107, 9707-9711.

Morato, T., Pitcher, T.J., Clark, M.R., Menezes, G., Tempera, F., Porteiro, F., Giacomello E., Santos, R.S., 2010b. Can we protect seamounts for research? A call for conservation. Oceanography 23 (1) 190-199.

Morato, T., Watson, R., Pitcher, T.J., Pauly, D., 2006. Fishing down the deep. Fish Fish. 7 (1) 24-34.

Myers, R.A., Worm, B., 2006. Rapid worldwide depletion of predatory fish communities. Nature 423, 280-283.

Nicol, S., Foster, J., Kawaguchi, S., 2012. The fishery for Antarctic krill - recent developments. Fish Fish. 13 (1) 30-40.

Norse, E.A., Brooke, S., Cheung, W.W.L., Clark, M.R., Ekeland, I., Froese, R., Gjerde, K.M., Haedrich, R.L., Heppell, S.S., Morato, T., Morgan, L.E., Pauly, D., Sumaila, R. Watson, R., 2012. Sustainability of deep-sea fisheries. Mar. Policy 36 (2) $307-$ 320.

O'Hara, T.D., 2007. Seamounts: centres of endemism or species richness for ophiuroids? Global Ecol. Biogeogr. 16, 720-732.

Olsson, P., Galaz, V., 2012. Social-ecological innovation and transformation. In: Nicholls, A., Murdoch, A. (Eds.), Social Innovation: Blurring Boundaries to Reconfigure Markets. Palgrave MacMillan, Basingstoke, UK.

Orr, J.C., Fabry, V.J., Aumont, O., Bopp, L., Doney, S.C., Feely, R.A., 2005. Anthropogenic ocean acidification over the twenty-first and its impact on calcifying organisms. Nature 437, 681-686.

Österblom, H., in press. Catching up on fisheries crime. Conserv. Biol., http:// dx.doi.org/10.1111/cobi.12229. Available online: http://onlinelibrary.wiley.com/doi/10.1111/cobi.12229/pdf (in press).

Österblom, H., Sissenwine, M., Symes, D., Kadin, M., Daw, T., Folke, C., 2011 Incentives, social-ecological feedbacks and European fisheries. Mar. Policy $35,568-574$

Österblom, H., Sumaila, U.R., 2011. Toothfish crises, actor diversity and the emergence of compliance mechanisms in the Southern Ocean. Global Environ. Change 21, 972-982.

Oude Elferink, A.G., 2012. Governance principles for areas beyond national jurisdiction. Int. J. Mar. Coastal Law 27, 205-259.

Papp, J.F., Bray, E.L., Edelstein, D.L., Fenton, M.D., Guberman, D.E., Hedrick, J.B. Jorgenson, J.D., Kuck, P.H., Shedd, K.B., Tolcin, A.C., 2008. Factors that Influence the Price of Al, Cd, Co, Cu, Fe, Ni, Pb, Rare Earth Elements, and Zn: U.S. Geological Survey Open-File Report 1356 USGS, USA.

Pauly, D., Belhabib, D., Blomeyer, R., Cheung, W.W.L., Cisneros-Montemayor, A.M Copeland, D., Harper, S., Lam, V.W.Y., Mai, Y., Le Manach, F., Österblom, H., Mok, K.M., van der Meer, L., Sanz, A., Shon, S., Sumaila, U.R., Swartz, W., Watson, R., Zhai, Y., Zeller, D., 2013. China's distant-water fisheries in the 21st century. Fish Fish Early View, http://dx.doi.org/10.1111/faf.12032.

Pauly, D., Christensen, V., Guénette, S., Pitcher, T.J.P., Sumaila, U., Walters, C., Watson, R., Zeller, D., 2002. Towards sustainability in world fisheries. Nature 418, 689-695.

Pitcher, T.J., Bulman, C., 2007. Raiding the larder: a quantitative evaluation framework and trophic signature for seamount food webs. In: Pitcher, T., Morato, T., Hart, P., Clark, M., Haggan, N., Santos, R. (Eds.), Seamounts: Ecology, Fisheries and Conservation. Blackwell Publishing, Oxford.

Ramirez-Llodra, E., Brandt, A., Danovaro, R., De Mol, B., Escobar, E., German, C.R., Levin, L.A., Martinez Arbizu, P., Menot, L., Buhl-Mortensen, P., Narayanaswamy, B.E., Smith, C.R., Tittensor, D.P., Tyler, P.A., Vanreusel, A., Vecchione, M., 2010. Deep, diverse and definitely different: unique attributes of the world's largest ecosystem. Biogeosciences 7 (9) 2851-2899.

Ramirez-Llodra, E., Tyler, P.A., Baker, M.C., Bergstad, O.A., Clark, M.C., Escobar, E. Levin, L.A., Menot, L., Rowden, A.A., Smith, C.R., Van Dover, C.L., 2011. Man and the last great wilderness: human impact on the deep sea. PLoS ONE 6 (8) e22588, http://dx.doi.org/10.1371/journal.pone.0022588.

Rice, J., Gjerde, K.M., Ardron, J.M., Arico, S., Cresswell, I., Escobar, E., Grant, S., Vierros, M., 2011. Policy relevance of biogeographic classification for conservation and management of marine biodiversity beyond national jurisdiction, and the GOODS biogeographic classification. Ocean Coastal Manage. 54 (2) 110-122. 
Rittel, W.J.H., Webber, M.M., 1973. Dilemmas in a general theory of planning. Policy Sci. 4, 155-169.

Rockström, J., Steffen, W., Noone, K., Persson, Å., Chapin III, F.S., Lambin, E.F., Lenton, T.M., Scheffer, M., Folke, C., Schellnhuber, H.J., Nykvist, B., de Wit, C.A., Hughes, T., van der Leeuw, S., Rodhe, H., Sörlin, S., Snyder, P.K., Costanza, R., Svedin, U., Falkenmark, M., Karlberg, L., Corell, R.W., Fabry, V.J., Hansen, J., Walker, B.H., Liverman, D., Richardson, K., Crutzen, P., Foley, J.A., 2009. A safe operating space for Humanity. Nature 461, 472-475.

Rogers, A.D., 1994. The biology of seamounts. Adv. Mar. Biol. 30, 305-350.

Roe, E., Schulman, P.R., 2008. High Reliability Management - Operating on the Edge. Stanford University Press, Stanford, CA.

Royal Dutch Shell, 2013. Perdido Development Project Site. Available at: http:/ www.shell.com/global/aboutshell/major-projects-2/perdido.html (accessed 05.09.13).

Salpin, C., Germani, V., 2007. Patenting of research results related to genetic resources from Areas Beyond National Jurisdiction: the crossroads of the Law of the Sea and Intellectual Property Law. Rev. Eur. Community Int. Environ. Law 16, 12-23.

Scheffer, M., Carpenter, S., Foley, J.A., Folke, C., Walker, B., 2001. Catastrophic shifts in ecosystems. Nature 413, 591-596.

Sea Around Us Project, 2013. A Global Database on Marine Fisheries and Ecosystems. Fisheries Centre, University British Columbia, Vancouver, British Columbia, Canada. Available at: www.seaaroundus.org.

Sealy, T., 1974. Soviet fisheries, a review. Mar. Fish. Rev. 36, 5-22.

Sibert, J., Hampton, J., Kleiber, P., Maunder, M., 2006. Biomass, size and trophic status of top predators in the Pacific Ocean. Science 314, 1773-1776.

Sumaila, U.R., Alder, J., Keith, H., 2006. Global scope and economics of illegal fishing. Mar. Policy 30, 696-703.

Schwartz, P., 1998. The Art of the Long View: Planning for the future in an Uncertain World. John Wiley \& Sons Inc., Chichester, West Sussex.

Swart, R.J., Raskin, P., Robinson, J., 2004. The problem of the future: sustainability science and scenario analysis. Global Environ. Change 14, 137-146.

Tacon, A.G.J., Metian, M., 2013. Fish matters: importance of aquatic foods in Human nutrition and global food supply. Rev. Fish. Sci. 21 (1) 22-38.
Takei, Y., 2012. Law and policy for International submarine cables: an Asia-Pacific perspective. Asian J. Int. Law 2 (2) 205-233.

Telegeography, 2013. Submarine Cable Map website. Available at: http://submarine-cable-map-2013.telegeography.com/ (accessed 12.09.13).

The Economist, 2013. Free Exchange: The Humble Hero. May 18th 2013. Available at: http://www.economist.com/news/finance-and-economics/21578041-containers-have-been-more-important-globalisation-freer-trade-humble (accessed 05.09.13).

Topper, B., Lagadec, P., 2013. Fractal crises - a new path for crisis theory and management. J. Conting. Crisis Manage. 21, 4-16.

U.S. Geological Survey (USGS), 2013. Mineral commodity summaries 2013. U.S. Geological Survey 198 p.

UN Convention on the Law of the Sea, 1982. Adopted 10 December 1982, entered into force 16 November 1994. No. 31363.

UN General Assembly Resolution 2749 (XXV), 1974. Declaration of Principles Governing the Sea-Bed and the Ocean Floor, and the Subsoil Thereof, Beyond the Limits of National Jurisdiction. GAR 2749.

UNEP/GRID-Arendal, 2011. Continental Shelf: The Last Maritime Zone. Arendal, Norway: UNEP/GRID-Arendal. Available at: http://www.grida.no/publications/ shelf-last-zone/ (accessed 18.02.13)

Van Dover, C.L., 1995. Ecology of mid-Atlantic Ridge hydrothermal vents. J. Geol. Soc. London (Special Publication) 87, 257-294.

Van Dover, C.L., Smith, C.R., Ardron, J., Dunn, D.C., Gjerde, K., Levin, L., Smith, S., Dinard Workshop Contributors, 2011. Designating networks of chemosynthetic ecosystem reserves in the deep sea. Mar. Policy 36 (2) 378-381.

Verne, J., 1870. Twenty Thousand Leagues Under the Sea. Plerre-Jules Hetzel, France. Villasante, S., Morato, T., Rodriguez-Gonzalez, D., Antelo, M., Österblom, H., Watling, L., Nouvian, C., Gianni, M., Macho, G., 2012. Sustainability of deep-sea fish species under the European Union Common Fisheries Policy. Ocean Coastal Manage. 70, 31-37.

Weick, K.E., Sutcliffe, K.M., 2001. Managing the Unexpected: Assuring High Performance in an Age of Complexity. Jossey Bass, A Wiley Company, San Francisco, CA.

Wilburn, D.R., 2011. Cobalt mineral exploration and supply from 1995 through 2013: U.S. Geological Survey Scientific Investigations Report: 508416 p. 